\title{
HUKUM KEPAILITAN DAN PERMASALAHANNYA DI INDONESIA
}

\author{
Oleh : \\ DR. Niru Anita Sinaga, SH, MH. \\ Dosen Tetap Fakultas Hukum Universitas Dirgantara Marsekal Suryadarma dan \\ Ketua LKBH Fakultas Hukum Universitas Dirgantara Marsekal Suryadarma \\ Dan \\ Nunuk Sulisrudatin, SH, S.Ip, MSi \\ Ketua Program Studi Ilmu Hukum Universitas Dirgantara Marsekal Suryadarma
}

\begin{abstract}
Abstrak :
Krisis moneter yang terjadi di Indonesia pada pertengahan tahun 1997 telah memberi pengaruh tidak menguntungkan terhadap perekonomian nasional, sehingga menimbulkan kesulitan besar terhadap dunia usaha dalam menyelesaikan utang piutang untuk meneruskan kegiatannya, dan menimbulkan dampak yang merugikan masyarakat. Pada masa itu banyak permasalahan yang timbul. Banyak perusahaan yang kesulitan membayar kewajiban utangnya terhadap para kreditor dan lebih jauh lagi banyak perusahaan mengalami kebangkrutan (Pailit). Terperosoknya nilai tukar rupiah, setidaknya telah memunculkan 3 (tiga) negative terhadap perekonomian nasional, yaitu: Negative balance of payments, Negative spread, Negative equity. Kondisi di atas mengakibakan banyaknya perusahaanperusahaan yang diancam kebangkrutan karena kondisi perekonomian nasional dan ketidak mampuan untuk membayar utang-utang perusahaan yang pada umumnya dilakukan dalam bentuk dollar. Untuk mengatasi permasalahan ini dibutuhkan suatu peraturan perundangundangan yang mengatur masalah utang piutang ini secara cepat, efektif, efesien dan adil.. Namun dalam pelaksanaannya undang-undang ini juga masih banyak menimbulkan permasalahan-permasalahan. Untuk itu perlu solusi untuk mengatasinya, sehingga apa yang menjadi tujuan pembuatan undang-undang kepailitan itu sendiri dapat tercapai, yaitu keadilan bagi para pihak.
\end{abstract}

\begin{abstract}
The monetary crisis that occurred in Indonesia in mid-1997 has given unfavorable influence on the national economy, causing great hardship on the business community in resolving the debts to continue their activities, and impacts are detrimental to society. At that time a lot of the problems that arise. Many companies have trouble paying its debt obligations to creditors and further many companies into bankruptcy (Bankruptcy). Terperosoknya rupiah, has raised at least 3 (three) negatively affect the national economy, namely: Negative balance of payments, spread Negative, Negative equity. The above conditions resulted in an amount of companies that threatened bankruptcy for the national economy and the inability to pay debts of companies that is generally done in the form of dollars. To solve this problem we need a legislation governing debt, it is fast, effective, efficient and fair. However, in practice these laws still causes a lot of problems. For that we need a solution to overcome, so what is the purpose of making bankruptcy law itself can be achieved, namely justice for the parties
\end{abstract}




\section{A. PENDAHULUAN}

Krisis moneter yang terjadi di Indonesia pada pertengahan tahun 1997 telah member pengaruh tidak menguntungkan terhadap perekonomian nasional, sehingga menimbulkan kesulitan besar terhadap dunia usaha dalam menyelesaikan utang piutang untuk meneruskan kegiatannya, dan menimbulkan dampak yang merugikan masyarakat. Berbagai pihak menuntut perubahan UndangUndang Kepailitan yang lebih melindungi kepentingan dunia usaha serta untuk mempercepat pemulihan krisis ekonomi yang dialami Indonesia. Lembaga Konsultan (think tank) Econit Advisory Group menyebut tahun 1997 merupakan "Tahun Ketidakpastian" (A Year of Uncertainty) sedangkan Tahun 1998 merupakan "Tahun Koreksi" (A Year of Correction).

Pada masa itu banyak permasalahan yang timbul, al: Pada pertengahan tahun 1997 terjadi depresiasi secara drastic nilai tukar ruiah terhadap mata uang asing, khususnya US \$ dari sekitar Rp. 2.300,00 pada sekitar bulan Maret menjadi sekitar Rp. 5000,00 per US \$ pada akhir tahun 1997. Bahkan pada pertengahan tahun 1998 nilai tukar rupiah sempat menyentuh $\mathrm{Rp}$. $16.000,00$ per US \$. Kondisi perekonomian ini mengakibatkan keterpurukan terhadap pertumbuhan ekonomi yang sebelumnya positif sekitar $6-7 \%$ telah terkontraksi menjadi minus $13-14 \%$. Tingkat inflasi meningkat dari di bawah $10 \%$ menjadi sekitar 70\%. Banyak perusahaan yang kesulitan membayar kewajiban utangnya terhadap para kreditor dan lebih jauh lagi banyak perusahaan mengalami kebangkrutan (Pailit). Terperosoknya nilai tukar rupiah, setidaknya telah memunculkan 3 (tiga) negative terhadap perekonomian nasional, yaitu: ${ }^{1}$

1. Negative balance of payments; Neraca pembayaran negative terutama terjadi karena melonjaknya nilai tukar dalam valuta asing (valas) kalau dirupiahkan. Utang perusahaan swasta dan pemerintah yang cukup besar telah mempercepat beban neraca pembayaran sementara kenaikan nilai ekspor sebagai akibat "bonanza" dari terdepresiasinya nilai rupiah tidak dapat dengan segera dinikmati.

2. Negative spread; Negative spread terutama terjadi pada industry keuangan. Kebijakan pemerintah untuk menaikkan suku bunga untuk mengerem laju permintaan valas telah menyebabkan naiknya bunga bank. Sementara itu, dana yang terkumpul dari masyarakat sulit disalurkan karena jarang ada perusahaan yang mampu memperoleh margin di atas suku bunga.

3. Negative equity. Perusahaan yang terlanjur memperoleh kredit bank

\footnotetext{
${ }^{1}$ Zainal Asikin, Hukum Kepailitan dan Penundaan Kewajiban Pembayaran Utang, Jakarta: Pustaka Reka Cipta, 2013, hal 11.
} 
mengalami negative equity karena nilai kekayaannya dalam rupiah tidak cukup lagi dan bahkan berbeda jauh apabila dipersandingkan dengan nilai rupiah dari utang valas.

Kondisi di atas mengakibakan banyaknya perusahaan-perusahaan yang diancam kebangkrutan karena kondisi perekonomian nasional dan ketidak mampuan unutk membayar utang-utang perusahaan yang pada umumnya dilakukan dalam bentuk dollar. Untuk mengatasi permasalahan ini dibutuhkan suatu peraturan perundang-undangan yang mengatur masalah utang piutang inisecara cepat, efektif, efesien dan adil. Sebelumnya sudah ada yang mengatur yaitu Undang-undang kepailitan yang lama. Namun dianggap tidak mampu memenuhi kebutuhan para pelaku bisnins untuk menyelesaikan masalah utang piutang mereka secara cepat, efektif, efisien dan adil.

Untuk mengantisipasi banyaknya perusahaan yang mengalami kebangkrutan, maka lahirlah Perpu No. 1 Tahun 1998, menjadi UU. No. 4 Tahun 1998 pemerintah telah melakukan perubahan, penambahan dan penyempurnaan pasal-pasal yang terdapat dalam Faillisement Verordening Stb. 1905 No. 217 Jo. Stb. 1906 No. 348. Namun perubahan dan penyempurnaan tersebut dirasakan masih mengandung beberapa kelemahan terutama yang timbul dalam prakteknya. Kemudian lahir UndangUndang No. 4 ahun 2004 tentang Undang-Undang Kepailitan dan Penundaan Pembayaran Utang, mulai berlaku berlaku tanggal 18 Oktober 2004. Namun dalam pelaksanaannya undang-undang ini juga masih banyak menimbulkan permasalahanpermasalahan. Untuk itu perlu solusi untuk mengatasinya, sehingga apa yang menjadi tujuan pembuatan undang-undang kepailitan itu sendiri dapat tercapai, yaitu keadilan bagi para pihak.

Dalam praktek hukum, acapkali seorang yang berutang (debitor) lalai memenuhi kewajibannya atau prestasinya, bukan karena disebabkan oleh keadaan yang memaksa (overmacht). Keadaan yang demikian disebut dengan ingkar janji (wanprestasi).

Dalam hukum perdata dikenal tiga bentuk wanprestasi, yaitu :

1. Debitor tidak memenuhi prestasi sama sekali.

2. Debitor terlambat dalam memenuhi prestasi.

3. Debitor berprestasi tidak sebagaimana mestinya. ${ }^{2}$

Dan sebagian pengusaha di Indonesia melalui perusahaannya tidak melakukan perhitungan yang matang terhadap utang melalui pinjam meminjam dengan perusahaan dari luar negara tersebut.

2 Purwahid Patrik, Dasar-Dasar Hukum Perikatan (Perikatan Yang Lahir Dari Perjanjian Dan Dari Undang-Undang), CV. Mandar Maju, Bandung, 1994, hal 11 
Salah satunya, perusahaan bahkan mengalami kesulitan serius untuk memenuhi kewajiban pembayaran utang sehingga kreditor dirugikan secara ekonomis. Dalam kondisi seperti ini, hukum kepailitan diperlukan guna mengatur penyelesaian sengketa utang piutang antara debitor dan para kreditornya. ${ }^{3}$

Saat masuk dalam dunia perniagaan, apabila debitor tidak mampu atau tidak mau membayar utang-utangnya kepada kreditor (disebabkan oleh situasi ekonomi yang sulit atau keadaan terpaksa), maka debitor dapat mengajukan permohonan Penundaan Kewajiban Pembayaran Utang untuk menyelesaikan persoalan tersebut. Dapat pula debitor atau kreditor mengajukan permohonan pernyataan pailit dengan harapan agar debitor yang lalai tersebut dinyatakan pailit oleh hakim melalui putusannya.

Kepailitan merupakan suatu lembaga hukum perdata sebagai realisasi dari dua asas pokok yang terkandung dalam Pasal 1131 dan Pasal 1132 Kitab Undang Undang Hukum Perdata.

Pasal 1131 Kitab Undang Undang Hukum Perdata menetapkan sebagai berikut: "Segala kebendaan si berutang, baik yang bergerak maupun yang tak bergerak, baik yang sudah ada maupun yang baru akan

${ }^{3}$ Irna Nurhayati, Tinjauan Terhadap UndangUndang Kepailitan (UU No. 4 Tahun 1998), Mimbar Hukum Majalah Berkala Fakultas Hukum UGM No: 32/VI/1999, hal 41. ada di kemudian hari, menjadi tanggungan untuk segala perikatan perseorangan". ${ }^{4}$

Selanjutnya Pasal 1132 Kitab Undang Undang Hukum Perdata menentukan sebagai berikut di bawah ini: "Kebendaan tersebut menjadi jaminan bersama-sama bagi semua orang yang mengutangkan padanya, pendapatan penjualan bendabenda itu dibagi-bagi menurut keseimbangan, yaitu menurut besar kecilnya piutang masing-masing, kecuali apabila diantara para berpiutang itu ada alasan-alasan yang sah untuk didahulukan"5.

Tindakan Pailit adalah suatu sitaan umum atas semua kekayaan Debitur Pailit yang pengurusan dan pemberesannya dilakukan oleh Kurator dibawah pengawasan Hakim Pengawas. Harta pailit akan dibagikan sesuai dengan porsi besarnya tuntutan Kreditor. Prinsip kepailitan yang demikian ini merupakan realisasi dari ketentuan Pasal 1131 dan Kitab Undangundang Hukum Perdata, yaitu kebendaan milik Debitor menjadi jaminan bersama-sama bagi semua Kreditor yang dibagi menurut prinsip keseimbangan atau "Pari Pasu Prorata Parte". 6

Berdasarkan ketentuan dalam Pasal-pasal tersebut diatas jelaslah,

\footnotetext{
${ }^{4}$ Pasal 1131 Kitab Undang Undang Hukum Perdata

${ }^{5}$ Ibid, Pasal 1132

6 Jerry Hoff, Undang Undang Kepailitan Indonesia, Penerjemah Kartini Mulyadi, Jakarta: P.T. Tatanusa, 2000, hal 13.
} 
bahwa apabila debitor lalai dalam memenuhi kewajibannya atau prestasinya kreditor diberikan hak untuk melakukan pelelangan atas harta benda debitor. Hasil penjualan (pelelangan) itu harus dibagi secara jujur dan seimbang diantara para kreditor sesuai dengan perimbangan jumlah piutangnya masing-masing. Pada umumnya kepailitan berkaitan dengan utang debitor atau piutang kreditor. Seorang kreditor mungkin saja memiliki lebih dari satu piutang atau tagihan, dan piutang atau tagihan yang berbeda-beda itu diperlukan pula secara berbeda-beda didalam proses kepailitan. ${ }^{7}$

Perlu diperhatikan disini bahwa tidak semua debitor yang lalai tersebut dapat dimohonkan pailit, karena menurut Undang-Undang Nomor 37 Tahun 2004 tentang Kepailitan dan Penundaan Kewajiban Pembayaran Utang, yang merupakan manifestasi dari Pasal 1131 dan Pasal 1132 Kitab Undang Undang Hukum Perdata, harus ada beberapa syarat yang harus dipenuhi, diantaranya adalah debitor tersebut mempunyai dua atau lebih kreditor dan tidak membayar lunas sedikitnya satu utang yang telah jatuh waktu dan dapat ditagih (Pasal 2 ayat (1) Undang-Undang Nomor 37 Tahun 2004).

7 Sutan Remy Sjahdeini, Hukum Kepailitan (Memahami faillissementsverordening Juncto Undang-Undang No. 4 Tahun 1998), Jakarta : Pustaka Utama Grafiti, 2002, hal. 89

\section{B. RUMUSAN MASALAH}

1. Mengapa hukum kepailitan menimbulkan permasalahanpermasalahan dalam penerapannya di Indonesia?

2. Bagaimana upaya untuk mengatasi permasalahan yang ada dalam hukum kepailitan di Indonesia?

\section{PEMBAHASAN}

A. Tinjauan Tentang Kepailitan

\section{Pengertian Kepailitan}

Pasal 2 ayat (1) Undangundang Nomor 37 Tahun 2004 (UUKPKPU) yang mendefinisikan pailit sebagai: "Debitor yang mempunyai dua atau lebih kreditor dan tidak membayar lunas sedikitnya satu utang yang telah jatuh waktu dan dapat ditagih, dinyatakan pailit dengan putusan pengadilan baik atas permohonannya sendiri maupun atas permohonan satu atau lebih kreditornya". 8

Dari definisi di atas, dapat diketahui syarat untuk dapat dinyatakan pailit melalui putusan pengadilan adalah :

a. Terdapat minimal 2 orang kreditor ;

b. Debitor tidak membayar lunas sedikitnya satu utang; dan

${ }^{8}$ Pasal 2 ayat (1) Undang-undang Nomor 37 Tahun 2004 (UUK dan PKPU) 
c. Utang tersebut telah jatuh waktu dan dapat ditagih.

Pasal 2. Penjelasan Pasal 2 ayat (1) UUK dan PKPU menerangkan bahwa yang dimaksud dengan utang yang telah jatuh waktu dan dapat ditagih adalah kewajiban untuk membayar utang yang telah jatuh waktu, baik karena telah diperjanjikan dengan percepatan waktu penagihannya sebagaimana diperjanjikan, karena pengenaan sanksi atau denda oleh instansi yang berwenang, maupun karena putusan pengadilan, arbiter, atau majelis arbitrasi. Mengenai hal ini, UUK tidak memberi penjelasan, hanya menyebutkan bahwa utang yang tidak dibayar oleh debitor sebagaimana dimaksud dalam ketentuan ini, adalah utang pokok atau bunganya. Hal terakhir ini tidak terdapat dalam penjelasan Pasal 2 UUKPKPU. ${ }^{9}$

\section{Asas, Tujuan, Dan Fungsi Undang-Undang Kepailitan}

\section{Asas Hukum Kepailitan, yaitu:}

a. Pernyataan Pailit harus diputus dalam waktu yang tidak berlarut-larut;

b. Pengurus Perusahaan Yang Pailit harus bertanggungjawab atas pengelolaan perusahaan,

${ }^{9}$ Man Sastrawidjaya, Hukum Kepailitan dan Penundaan Kewajiban Pembayaran Utang, Alumni, Bandung, 2006, Hal.89-90. kecuali dapat membuktikan sebaliknya bahwa mereka tidak bersalah;

c. Dimungkinkan utang debitur dilakukan restrukturisasi sebelum diajukan permohonan pailit;

d. Kriminalisasi terhadap kecurangan debitur.

Tujuan Undang - undang Kepailitan:

a. Memberikan forum kolektif untuk memilih milah hak-hak dari berbagai penagih terhadap aset debitor yang tidak mencukupi untuk membayar utang;

b. Menjamin pembagian yang sama dan seimbang terhadap harta debitur sesuai dengan asas "pari passuh";

c. Mencegah agar debitur tidak melekukan tindakan yang merugikan para kreditor;

d. Melindungi kreditur konkuren untuk memperoleh hak mereka;

e. Memberikan kesempatan pada debitor dan para kreditornya untuk melakukan restrukturisasi utang debitur;

f. Memberikan perlindungan pada debitor yang beretikad baik dengan cara pembebasan hutang

\section{Fungsi Undang - undang Kepailitan adalah:}

a. Mengatur tingkat prioritas dan urutan masing-masing piutang kreditor; 
b. Mengatur tatacara agar seorang debitor dapat dinyatakan pailit;

c. Mengatur bagaimana tatacara menentukan kebenaran adanya piutang kreditor;

d. Mengatur syahnya piutang atau tagihan kreditor;

e. Mengatur tatacara pencocokan atau verifikasi dari tagihan kreditor;

f. Mengatur bagaimana tatacara membagi hasil penjualan harta kekayaan debitor sesuai prioritas dan urutan masingmasing kreditor;

g. Mengatur tata cara pendamaian yang ditempuh oleh debitor dengan para kreditor dan sesudah pernyataan pailit.

\section{Syarat - Syarat Untuk Dinyatakan Pailit}

a. Terdapat keadaan berhenti membayar, yakni bila seorang debitur sudah tidak mampu atau tidak mau membayar utang-utangnya.

b. Harus terdapat lebih dari seorang kreditur, dan salah seorang dari mereka itu, piutangnya sudah dapat ditagih.

Secara umum, untuk pernyataan kepailitan tidak perlu ditunjukan bahwa debitur tidak mampu untuk membayar utangnya, dan tidak diperdulikan, apakah berhenti membayar itu sebagai akibat dari tidak dapat atau tidak mau membayar.
Pembuktian tentang keadaan debitur yang " berhenti membayar "itu cukup dilakukan secara sederhana (sumier), artinya, pengadilan di dalam memeriksa perkara kepailitan itu tidak perlu terikat dengan system pembuktian dan alat-alat bukti yang ditentukan dalam hukum acara perdata.

Hakim dalam pemeriksaan permohonan kepailitan bersifat aktif, sedapat mungkin mendengar secara seksama kedua belah pihak (debitur dan kreditur) di depan persidangan, dan berusaha mendamaikan (akor/akur) diantara keduanya.

\section{Pihak - Pihak Yang Dapat Mengajukan Permohonan Kepailitan}

Pasal 2 ayat 1 UU No.37 Tahun 2004, yang dapat mengajukan kepailitan adalah:

a. Debitur sendiri

b. Seorang Kreditur atau lebih

c. Jaksa atau penuntut umum

d. Bank Indonesia apabila debiturnya adalah Bank;

e. Badan Pengawas Pasar Modal apabila debiturnya adalah perusahaan Efek, Bursa Efek, Lembaga Kliring dan Penjamin, Lembaga Penyimpan dan Penyelesaian;

f. Menteri Keuangan apabila debiturnya adalah Perusahaan Asuransi, Reasuransi, Dana Pensiun dan Badan Usaha Milik Negara. 


\section{Beberapa Hal Penting:}

a. Secara normatif seorang kreditur dapat mengajukan permohonan kepailitan terhadap debitur.

b. Dalam praktek peradilan, seorang kreditur tidak boleh mengajukan permohonan kepailitan, tujuannya membagi harta kekayaan debitur dengan para penagih lainnya."

c. Jaksa berhak untuk mewakili Negara dalam perkara perdata dimuka pengadilan, merupakan pengecualian terhadap tugas dan wewenang kejaksaan yang khusus menangani persoalanpersoalan

pidana=>"kepentingan umum" adalah kepentingan bangsa dan Negara dan/atau kepentingan masyarakat luas.

Tindakan debitur yang akan merugikan masyarakat dan menghambat proses pembayaran hutang. Penjelasan pasal 2 ayat 2 UU No. 37 Tahun 2004:

a. Debitur melarikan diri

b. Debitur menggelapkan bagian dari harta kekayaan

c. Debitur mempunyai utang kepada Badan Usaha Milik Negara atau badan usaha lainnya yang menghimpun dana dari masyarakat

d. Debitur mempunyai utang yang berasal dan penghimpunan dana dari masyarakat luar

e. Debitur tidak beritikad baik atau tidak kooperatif dalam menyelesaikan masalah utang piutang yang telah jatuh waktu atau

f. Dalam hal lainnya menurut kejaksaan merupakan kepentingan umum

Tata cara pengajuan permohonan pailit sama dengan permohonan pailit yang diajukan oleh Debitur atau Kreditur Permohonan pailit dapat diajukan oleh kejaksaan tanpa menggunakan advokat.

6. Acara Tata Cara Permohonan Kepailitan:

a. Pemeriksaan kepailitan didahului dengan adanya "permohonan kepailitan" oleh pihak-pihak yang berwenang (debitur, kreditur, kejaksaan dan sebagainya) diajukan kepada Ketua Pengadilan Niaga yang berwenang.

1) Panitera akan mendaftarkan pada tanggal permohonan kepada pemohon diberikan tanda diterima.

2) Panitera menyampaikan permohonan pernyataan pailit kepada Ketua Pengadilan paling lambat 2 (dua) hari setelah tanggal permohonan didaftarkan

3) Paling lambat 3 (tiga) hari setelah tanggal permohonan pernyataan pailit didaftarkan, Pengadilan mempelajari permohonan dan menetapkan hari sidang. 
4) Sidang pemeriksaan di selengarakan paling lambat 20 (dua puluh) hari setelah tanggal permohonan didaftarkan.

5) Atas permohonan Debitur dan berdasarkan alasan yang cukup, pengadilan dapat menunda paling lambat 25 (dua puluuh lima) hari setelah tanggal permohonan didaftarkan

Beda UU yg lama dan Undangundang No. 37 Tahun 2004: permohonan tertulis atau diajukan oleh advokat, dikecualikan bagi permohonan yang diajukan oleh Kejaksaan, Bank Indonesia, Badan Pengawas Pasar Modal dan Menteri Keuangan (Pasal 7).

Umumnya suatu permohonan kepailitan dilakukan oleh para pihak secara tertutup atau tidak diumumkan secara terbuka, Namun pernah juga diumumkan dlm mass media (Koran), contoh: PT Perusahaan Rokok Tjap Bentoel Malang diajukan kepailitan para kreditornya

b. Setelah pengadilan menerima permohonan kepailitan maka:

1) Panitera atau pejabat yang mewakilinya "wajib" memanggil debitur, jika permohonan itu diajukan oleh kreditur.

2) Jika permohonan diajukan oleh debitur, maka Pengadilan "tidak wajib/dapat" memanggil kreditur. (Pasal 8).
3) Pemanggilan dilakukan oleh juru sita dengan surat kilat tercatat paling lambat 7 (tujuh) hari sebelum siding pemeriksaan pertama diselenggarakan.

4) Pemanggilan sah dan dianggap telah diterima oleh debitur, jika dilakukan oleh juru sita.

5) Permohonan pernyataan pailit harus dikabulkan apabila terdapat fakta atau keadaan yang terbukti secara sederhana bahwa persyaratan untuk dinyatakan pailit sebagaimana dimaksud dalam Pasal 2 ayat (1) telah dipenuhi.

6) Selama pemeriksaan permohonan kepailitan, hakim atau pengadilan dapat memerintahkan panitera atau wakilnya untuk melakukan penyegelan terhadap harta kekayaan (boedel) dar isi debitur (atas permohonan krediturnya)=>untuk menghindari hal-hal yang merugikan krediturnya.

7) Putusan Pengadilan atas permohonan pernyataan pailit:

8) Paling lambat 60 hari setelah tanggal permohonan pernyataan pailit didaftarkan.

9) Putusan Pengadilan wajib memuat: Pasal yang menjadi dasar hukum, sumber hukum tak tertulis, pertimbangan hukum dan perbedaan pendapat hakim kalau ada

10) Putusan memuat: pertimbangan hukum, 
diucapkan dalam siding terbuka untuk umum dan dapat dilaksanakan terlebih dahulu, meskipun terhadap putusan tersebut di ajukan suatu upaya hukum.

11) Salinan putusan Pengadilan $=>$ disampaikan oleh juru sita=> kepada debitur, pihak yang mengajukan permohonan pernyataan pailit, Kurator, dan Hakim Pengawas $=>\max 3$ hari setelah tanggal putusan

12) Jika putusan belum diucapkan $=>\quad$ Kreditor, kejaksaan, Bank Indonesia, Badan Pengawas Pasar Modal, atau Menteri Keuangan dapat mengajukan permohonan kepada Pengadilan untuk:

a) Meletakan sita jaminan terhadap sebagian atau seluruh kekayaan debitur; atau

b) Menunjuk Kurator sementara untuk mengawasi: i) pengelolaan usaha debitur; dan ii) pembayaran kepada Kreditur, pengalihan, kekayaan Debitur yang dalam kepailitan merupakan wewenang Kurator.

13) Putusan kepailitan bersifat konstitutif, yaitu putusan meniadakan keadaan hukum atau menimbulkan keadaan hukum yang baru.

14) Salinan putusan Pengadilan wajib disampaikan juru sita kepada Debitur, pihak yang mengajukan permohonan pernyataan pailit, Kurator, dan Hakim Pengawas paling lambat 3 hari setelah tanggal putusan

15) Dengan dijatuhkannya putusan kepailitan, maka demi hukum Kurator akan bertindak menjadi kuratris (pengampu) si pailit.

16) Kuratorlah yang bertugas mengurus harta (boedel) sipailit, dan segala hubungan surat menyurat yang dialamatkan kepada si pailit.

\section{Akibat - akibat Hukum Putusan Kepailitan Bagi Si Pailit Dan Hartanya}

a. Sejak diucapkannya putusan kepailitan, ia kehilangan hak untuk melakukan pengurusan dan penugasan atas harta bendanya (persona Standi in ludicio) $=>$ pasal 24 UU No. 37 Tahun 2004.

b. Pengurusan dan penguasaan harta pailit itu akan beralih ke tangan kurator, dan kurator akan bertindak selaku pengampu.

c. Si pailit masih diperkenankan untuk melakukan perbuatanperbuatan hukum di bidang harta kekayaan, cth: membuat perjanjian $=>$ memberikan keuntungan bagi harta (boedel) si pailit, kalau rugi tidak mengikat boedel.

d. Kurator harus pula memperhatikan keadaan si Pailit, artinya apabila dianggap 
perlu, demi kebutuhan hidup si pailit, maka kkurator harus membayar tunjangan hidup si pailit.

\section{B. Beberapa Permasalahan Dalam Hukum Kepailitan di Indonesia}

Implementasi UU Kepailitan 2004 malah tak semudah yang dibayangkan. "Justru lebih berat dari UU Kepailitan tahun 1998. Padahal, krisis moneter sudah lewat," Substansi UU Kepailitan dan PKPU bertentangan dengan hakekat dari hukum kepailitan. UU Kepailitan seolah menjadi mesin pembunuh bagi kelanjutan usaha dari debitor.

\section{Beberapa permasalahan terjadi, antara lain:}

1. Syarat minimum kreditor sebagai pemohon pailit. Pasal 2 ayat (1) UU Kepailitan menegaskan pailit bisa dimohonkan jika memenuhi dua syarat: debitor mempunyai dua kreditor atau lebih dan debitor tidak membayar sedikitnya satu utang yang telah jatuh tempo dan dapat ditagih. Sejak dikeluarkanya UndangUndang Kepailitan tahun 1998, permohonan pernyataan palit terhadap debitor begitu mudahnya. Hal ini berakibat terhadap banyaknya debitor yang dinyatakan pailit, meskipun dalam tingkat kasasi kepailitan tersebut dibatalkan, misalnya, dikabulkannya permohonan pailit terhadap Modernland, Manulife, dan Prudential. Modern land dipailitkan karena gagal menyerahkan unit apartemen kepada pembelinya, Manulife dipailitkan karena sengketa antara pemegang saham, dan Prudential dipailitkan karena sengketa kontraktual. Kasus yang paling besar ialah dipalitkanya suatu BUMN yaitu PT Dirgantara Indonesia karena dalam sejarah ini baru pertama kali BUMN dipailitkan. Dalam hal ini bisa timbul:

a. Pasal ini, dinilai menjadi bukti bahwa UU Kepailitan bertentangan dengan hakekat dibutuhkannya upaya hukum kepailitan yang seharusnya untuk kepentingan seluruh kreditor.

b. Prakteknya, bisa timbul masalah ketika kreditor lain yang bukan pemohon pailit dan tagihannya sudah jatuh tempo atau belum jatuh tempo tidak berniat untuk melakukan tindakan hukum (mempailitkan debitor). "Akibatnya para kreditor lain terpaksa ikut mendaftar sebagai kreditor,"

c. Jumlah kreditor sebagai pemohon pailit harus ditambah. Syarat debitor dapat dipailitkan juga harus memenuhi bukti bahwa minimum 75 persen kreditor memiliki utang dan sudah jatuh tempo, plus tidak dibayar. 
d. Debitor juga dibebani untuk membuktikan bahwa minimum 75 persen kreditor memiliki piutang yang sudah jatuh tempo. Jika hanya ada satu kreditor, kata Hotman, perkara tersebut bisa diselesaikan melalui jalur gugatan perdata biasa atau permohonan eksekusi jaminan dengan syarat ada perbaikan proses perkara perdata dari sisi waktu.

2. Jangka waktu PKPU yang sangat singkat.

a. Ide dasar dari PKPU adalah memberikan kesempatan bagi debitor untuk mereorganisasi atau menata ulang usahanya. Penataan kembali bisnis itu membutuhkan waktu yang tidak sedikit.

b. waktu yang diberikan oleh UU Kepailitan hanya 45 hari. Waktu 45 hari ini dinilai sulit digunakan untuk menyelesaikan proposal perdamaian, lobi, dan reorganisasi usaha.

c. Jika kreditor yang mengajukan PKPU. Debitor dipaksa untuk mengajukan proposal perdamaian untuk seluruh kreditor. Idealnya, kreditor juga ikut mengajukan proposal perdamaian.

d. Kreditor separatis berhak mempailitkan dan ikut dalam voting tanpa kehilangan hak atas agunannya. Ada ketidakadilan, dimana hak kreditor telah dilindungi oleh agunan atas kekayaan debitor, namun debitur tetap dipailitkan atas voting dari kreditor separatis tersebut.

e. Tingginya syarat perhitungan suara dan harus dipenuhi syarat kumulatif voting kreditor konkuren dan kreditor separatis yang diatur dalam Pasal 281 UU Kepailitan, menjadi penyebab utama upaya hukum PKPU sangat kejam. Bahkan ini juga menjadi penghambat utama proposal perdamaian yang diajukan oleh debitor sering mengalami kekalahan.

f. "Dalam praktek sering terjadi hanya kurang lebih satu tahun sesudah homologasi atas composition plan ternyata debitor gagal bayar karena memang sejak awal telah dipaksa. Jadi debitor itu dipaksa untuk membuat proposal perdamaian yang memukau para kreditor padahal sebenarnya sudah tak mampu bayar," tambah Hotman.

g. Terkait honorarium atau fee curator (pengurus). Saat ini, aturan untuk honorarium kurator didasarkan pada persentase total aset debitor atau presentasi dari total jumlah utang. Aturan ini dinilai menjadi penyebab 'kanibalisme' dan 'permainan' oknum-oknum yang memiliki kepentingan dan mendapatkan keuntungan atas hal tersebut. 
h. Terjadi multi tafsir atas peringkat tagihan pajak, tagihan upah buruh, dan piutang kreditor separatis.

\section{Upaya Mengatasi Permasalahan Dalam Hukum Kepailitan di Indonesia}

1. Melakukan revisi terhadap Pasal 2 ayat (1) UU Kepailitan. Pasal ini tidak memperhitungkan apakah debitor mampu atau tidak mampu untuk membayar seluruh utang. Revisi harus mengatur secara jelas peringkat kreditor dan renvoi prosedur Revisi UU Kepailitan dan PKPU harus disinkronisasi dengan UU yang saling berkaitan seperti UU Perseroan Terbatas, UU tentang Larangan Praktek Monopoli dan Persaingan Usaha Tidak Sehat, dan UU Penanaman Modal.

2. Pentingnya hakim niaga lebih memahami seluk beluk kepailitan. Kepailitan memang rentan untuk dipakai nggak benar, tetapi juga penting bagi perusahaan yang memang punya aset tapi tidak mau bayar. Sehingga Hakim di Pengadilan Niaga pun harus benar-benar memahami seluk beluk kepailitan. Jangan tiap dua tahun diganti, jadinya susah karena harus menjelaskan dari awal lagi,"

3. Seharusnya PKPU diajukan oleh debitor. Faktanya, PKPU justru sebagian besar diajukan oleh kreditor karena UU Kepailitan dan PKPU mengizinkan hal tersebut. ketentuan ini dinilai salah kaprah. Oleh karenanya perlu dilakukan revisi yang menegaskan bahwa PKPU tak boleh diajukan oleh kreditor dan hanya dapat diajukan oleh debitor secara voluntary. Namun jika dengan segala pertimbangan kreditor dimungkinkan untuk mengajukan PKPU maka putusan PKPU harus membuka peluang kasasi bagi debitor.

4. Kapitalis modern adalah untuk menggalakkan reorganisasi perusahaan. Hukum Kepalitan harus memberikan waktu cukup bagi perusahaan untuk melakukan pembenahan perusahaan.

5. Hukum kepailitan mestinya tidak hanya memperhatikan kreditur dan debitur tetapi yang lebih penting lagi adalah memperhatikan kepentingan stakeholder yang dalam kaitan ini yang terpenting adalah pekerja.

6. Ketentuan kepailitan memang telah memberikan hak istimewa untuk pembayaran gaji buruh yang terutang. Akan tetapi bagaimana dengan hak-hak buruh lainnya. Disamping itu juga perlu dilihat apakah pailit menimbulkan dampak luas bagi konsumen atau menyebabkan terjadinya dislokasi ekonomi yang buruk. Singkat kata, kepailitan adalah ultimum remedium, upaya terakhir.

7. Pasal 2 ayat 5 UU Kepailitan menyatakan bahwa dalam hal Debitur adalah Badan Usaha Milik Negara yang bergerak di bidang kepentingan publik, maka 
permohonan pernyataan pailit hanya dapat diajukan oleh Menteri Keuangan. Namun, BUMN yang dimaksud dalam Undang-Undang tersebut tidak dapat kita tafsirkan semua BUMN yang ada di Indonesia.

8. Terkait dengan Pasal 2 UndangUndang Kepailitan yang mengatur tentang pihak-pihak yang dapat mengajukan permohonan pailit terhadap instansi-instansi tertentu. Pasal 2 ayat (3) menyatakan bahwa Dalam hal Debitor adalah bank, permohonan pernyataan pailit hanya dapat diajukan oleh Bank Indonesia. Dikaitkan dengan Pasal 2 ayat (5) juga, timbul pertanyaan baru yakni bagaimana jika debitor adalah sebuah BUMN dalam bentuk bank, maka siapakah yang berhak mengajukan permohonan pailit terhadapnya? Menteri Keuangan ataukah bank Indonesia?

9. Dalam hukum kepailitan di Indonesia, tidak memperhatikan kesehatan keuangan dari debitor. jadi meskipun keuangan debitor itu solven tetap bisa dipailitkan sepanjang sudah memenuhi syarat adanya utang yang tidak dibayar lunas serta adanya dua kreditor atau lebih.

10. Pasal $10 \quad$ Undang-Undang Kepailitan memungkinkan diletakkannya sita jaminan terhadap sebagian atau seluruh kekayaan kreditor. Prosedur permintaan dan penetapan sita jaminan dalam kepailitan memang mengacu pada ketentuan pasal 10
Undang-Undang Kepailitan.

Dalam prakteknya, pemohon pailit biasanya memang meminta kepada Pengadilan Niaga terhadap kekayaan Termohon pailit diletakkan sita jaminan. Namun dalam prakteknya pula, permintaan sita jaminan tersebut tidak pernah dikabulkan oleh Pengadilan Niaga. Karena, pertama, acara pemeriksaan di Pengadilan Niaga berlangsung dengan acara sumir (sederhana) dan waktunya singkat (dalam 30 hari harus sudah ada putusan). Tanpa prosedur sita jaminan saja, proses persidangan dan pemeriksaan perkara kepailitan sudah sangat "mepet" timelinenya. Kedua, hakekat dari pernyataan pailit sendiri adalah sitaan umum terhadap harta benda debitur yang ada sekarang maupun di masa yang akan datang. Oleh karena itu, tanpa meminta sita jaminan pun, apabila debitur dinyatakan pailit maka otomatis pernyataan tersebut merupakan sitaan umum dan tidak perlu lagi meminta sita jaminan ke pengadilan negeri. Jadi permohonan pailit yang disertai permintaan sita jaminan selama ini tidak pernah ada yang dikabulkan oleh Majelis Pengadilan Niaga karena mereka beranggapan seandainya nanti debitur dinyatakan pailit, maka otomatis seluruh harta benda debitur menjadi sitaan umum yang digunakan untuk melunasi 
utangnya kepada krediturkrediturnya.

\section{PENUTUP}

\section{Kesimpulan Dan Saran}

\section{A. Kesimpulan}

1. Implementasi UU Kepailitan 2004 malah tak semudah yang dibayangkan. "Justru lebih berat dari UU Kepailitan tahun 1998. Padahal, krisis moneter sudah lewat," Substansi UU Kepailitan dan PKPU bertentangan dengan hakekat dari hukum kepailitan. UU Kepailitan seolah menjadi mesin pembunuh bagi kelanjutan usaha dari debitor. Beberapa permasalahan terjadi, antara lain: Syarat minimum kreditor sebagai pemohon pailit yang terdapat pada Pasal 2 ayat (1) , Jangka waktu PKPU yang sangat singkat, Jika kreditor yang mengajukan PKPU. Debitor dipaksa untuk mengajukan proposal perdamaian untuk seluruh kreditor. Idealnya, kreditor juga ikut mengajukan proposal perdamaian, Kreditor separatis berhak mempailitkan dan ikut dalam voting tanpa kehilangan hak atas agunannya. Ada ketidakadilan,Tingginya syarat perhitungan suara dan harus dipenuhi syarat kumulatif voting kreditor konkuren dan kreditor separatis yang diatur dalam Pasal 281 UU Kepailitan, "Dalam praktek sering terjadi hanya kurang lebih satu tahun sesudah homologasi atas composition plan ternyata debitor gagal bayar karena memang sejak awal telah dipaksa, honorarium atau fee curator (pengurus) sangat tinggi. kepentingan dan mendapatkan keuntungan atas hal tersebut, Terjadi multi tafsir atas peringkat tagihan pajak, tagihan upah buruh, dan piutang kreditor separatis.

2. Upaya Mengatasi Permasalahan Yang Ada, adalah dengan Cara: Melakukan revisi terhadap Pasal 2 ayat (1) UU Kepailitan, Pentingnya hakim niaga lebih memahami seluk beluk kepailitan, Seharusnya PKPU diajukan oleh debitor, Hukum Kepalitan harus memberikan waktu cukup bagi perusahaan untuk melakukan pembenahan perusahaan, Hukum kepailitan mestinya tidak hanya memperhatikan kreditur dan debitur tetapi yang lebih penting lagi adalah memperhatikan kepentingan stakeholder yang dalam kaitan ini yang terpenting adalah pekerja, Perlu dilihat apakah pailit menimbulkan dampak luas bagi konsumen atau menyebabkan terjadinya dislokasi ekonomi yang buruk, Hukum kepailitan di Indonesia harus memperhatikan kesehatan keuangan dari debitor, Prosedur permintaan dan penetapan sita jaminan harus lebih ditegaskan pengaturannya. 


\section{B. Saran}

1. Undang-Undang Kepailitan dan PKPU perlu direvisi, antara lain: Syarat minimum kreditor sebagai pemohon pailit, Perbandingan jumlah utang dan aset yang ada harus jadi pertimbangan.

2. Hakim yang nangani kepailitan harus benar-benar yang ahli dibidangnya.

\section{DAFTAR PUSTAKA}

\section{A. Buku}

Irna Nurhayati, Tinjauan Terhadap Undang-Undang Kepailitan (UU No. 4 Tahun 1998), Mimbar Hukum Majalah Berkala Fakultas Hukum

UGM No: 32/VI/1999.

Jerry Hoff, Undang Undang Kepailitan Indonesia, Penerjemah Kartini Mulyadi, Jakarta: P.T. Tatanusa, 2000.

Man Sastrawidjaya, Hukum Kepailitan dan Penundaan Kewajiban Pembayaran Utang, Alumni, Bandung, 2006.

Sutan Remy Sjahdeini, Hukum Kepailitan (Memahami faillissementsverordening Juncto Undang-Undang No. 4 Tahun 1998), Jakarta : Pustaka Utama Grafiti, 2002.

Purwahid Patrik, Dasar-Dasar Hukum Perikatan (Perikatan Yang Lahir Dari Perjanjian Dan Dari Undang-Undang), CV. Mandar Maju, Bandung, 1994.
Zainal Asikin, Hukum Kepailitan dan Penundaan Kewajiban Pembayaran Utang, Jakarta: Pustaka Reka Cipta, 2013.

\section{B. Peraturan Perundang-Undangan}

Kitab Undang-Undang Hukum Perdata

Undang-undang Nomor 37 Tahun 2004 Tentang Kepailitan dan PKPU 